\title{
HUBUNGAN STATUS GIZI ANAK DENGAN PERKEMBANGAN MOTORIK KASAR PADA ANAK USIA BAYI DAN BALITA (0-59 BULAN) DI PUSKESMAS PANDANWANGI MALANG
}

\author{
Caesar Ensang Timuda
}

Rumah Sakit Umum Daerah Kediri

\begin{abstract}
ABSTRAK
Hubungan Antara Status Gizi Dengan Perkembangan Motorik Kasar Anak Usia Bayi Dan Balita (0-59 Bulan) Di Puskesmas Pandanwangi Malang. Latar Belakang: Kecukupan pangan yang esensial baik kualitas maupun kuantitas sangat penting untuk pertumbuhan normal. Salah satu parameter perkembangan anak adalah perkembangan motorik kasar yaitu aspek yang berhubungan dengan pergerakan dan sikap tubuh yang melibatkan otot-otot besar. Tujuan: Mengetahui hubungan antara status gizi dengan perkembangan motorik kasar anak usia bayi dan balita (0-59 bulan) di Puskesmas Pandanwangi Malang. Metode: Analitik observasional dengan pendekatan cross sectional. Pengambilan sampel secara cluster sampling dengan populasi 148 responden. Jumlah sampel 122 responden. Dianalisa dengan uji chi square. Hasil Penelitian: $29,5 \%$ responden mengalami keterlambatan perkembangan motorik kasar yang terdiri dari 3,3\% responden sangat kurus, $7,4 \%$ responden kurus, $15,6 \%$ responden normal dan 3,3\% anak gemuk, dengan nilai p sebesar 0,000 dan $\alpha=0,05$. Kesimpulan: Terdapat hubungan yang sangat signifikan antara status gizi dengan perkembangan motorik kasar.
\end{abstract}

\begin{abstract}
The correlation between Nutritional Status and Gross Motoric Developmenton Under Five's Children (059 months) in Pandanwangi Health Center Malang. Backgrounds: Lack of essential food,either in quality or quantity is very important for normal growth. One of the parameter in cbild development is the gross motoric development, which is an aspect that is related to the movement and body posture that involve large muscles. Objectives: To study the correlation between nutritional status and gross motoric development on under five's children (0-59 months) in Pandanwangi Health Center Malang. Methods: Observational analytics with cross sectional approach. Samples were taken using cluster sampling technique with population consisted of 148 people. Samples consisted of 122 people. Data were analyzed by using chi- squaref) test. Results: $29.5 \%$ children undervent delay on gross motoric development consisted of $3.3 \%$ very thin children, $7.4 \%$ thin children, $15,6 \%$ normal cbildren and $3.3 \%$ fat children, with $p$ value was 0,000 and $a=0,05$. Conclusion: There was a very significant relation between the nutritional status and gross motoric development.
\end{abstract}

Key words: Nutritional status, Gross motoric development, Under five's cbildren

\section{PENDAHULUAN}

Kualitas anak masa kini merupakan penentu kualitas sumber daya manusia (SDM) yang akan datang (Tanuwijaya, 2002). Kecukupan pangan yang essensiil baik kualitas maupun kuantitas sangat penting untuk pertumbuhan normal. (Suyitno, 2002). Jumlah penderita gizi buruk dan gizi kurang ini sekitar $28 \%$ dari total balita di seluruh Indonesia. Dari jumlah balita penderita gizi buruk dan kurang, sekitar $10 \%$ berakhir dengan kematian. Dari angka kematian balita yang 37 per 1.000 ini, separuhnya adalah kekurangan gizi. (Depsos, 2006).

Di Indonesia menurut data Survei Sosial Ekonomi Nasional (Susenas) tahun 1989, ditemukan prevalensi KEP mencapai 10,48\% dan gizi buruk sekitar 1,32\%. Kemudian tahun 1992, prevalensi KEP meningkat menjadi 35,5\% dan tahun 1995 menurun kembali menjadi 14,6\%. Berdasarkan SKRT tahun 1995 prevalensi gizi kurang dan gizi buruk di Jawa Tengah mencapai 10-15\%. Hasil tersebut tidak jauh berbeda dengan hasil Susenas 1995 untuk Jawa Tengah yaitu
10,1\%. Data prevalensi Balita gizi buruk setelah krisis ekonomi diperkirakan lebih tinggi lagi. (Tarigan, 2003).

Pertumbuhan dan perkembangan pada tahap awal menentukan perkembangan selanjutnya. Salah satu parameter perkembangan anak adalah perkembangan motorik kasar yaitu aspek yang berhubungan dengan pergerakan dan sikap tubuh yang melibatkan otot-otot besar (UKK Tumbuh Kembang - Pediatri Sosial IDAI, 2010). Perkembangan motorik kasar meliputi duduk, berjalan, berdiri, dan melakukan gerakan umum otot besar lainnya. Parameter perkembangan yang lainnya adalah motorik halus, kemampuan berbicara dan berbahasa dan aspek sosial kemandirian. (Nugroho, 2009). Penelitian hubungan status gizi anak dengan perkembangan motorik kasar pada anak usia bayi dan balita (0-59 bulan) di Pandanwangi Malang dilakukan karena berdasarkan data dari kota Malang, prevalensi balita gizi kurang pada tahun 2010 tercatat paling tinggi di antara puskesmas yang lain. 
Tujuan penelitian ini untuk mengetahui hubungan antara gambaran status gizi dengan gambaran perkembangan motorik kasar anak usia bayi dan balita (0-59 bulan) di Puskesmas Pandanwangi Malang. Manfaat Penelitian ini adalah dapat memberi pengetahuan kepada kepada praktisi kesehatan terhadap gangguan perkembangan motorik kasar. Mampu mengurangi angka kejadian gangguan perkembangan motorik kasar. Hasil penelitian ini dapat berguna sebagai dasar atau sumber data untuk penelitian berikutnya, serta pendorong bagi pihak-pihak yang ingin melakukan penelitian lebih lanjut. Sebagai sumber informasi untuk mengetahui pentingnya memelihara status gizi pada anak demi perkembangan anak.

\section{METODE PENELITIAN}

Desain penelitian yang digunakan adalah analitik observasional dengan pendekatan cross sectional. Lokasi di Puskesmas Pandanwangi Malang pada bulan Januari-Febuari 2012. Sampel penelitian ini adalah anak yang masih berada di usia bayi dan balita (0-59 bulan) yang tinggal di Puskesmas Pandanwangi yang memenuhi kriteria inklusi dan eksklusi. Kriteria inklusi yang dimaksud adalah anak usia bayi dan balita (0-59 bulan) yang tinggal di Pandanwangi, tidak dalam keadaan sakit kronik, kooperatif (tidak tidur, tidak mengantuk, tidak lelah, tidak rewel) saat dilakukan seluruh pemeriksaan. Kriteria eksklusi yang dimaksud adalah anak yang tidak diizinkan oleh orang tuanya untuk diteliti atau memakai terapi jangka panjang.

Pada penelitian ini status gizi adalah keadaan tubuh akibat konsumsi makanan dan penggunaan zat gizi, dengan parameter yang dipakai adalah berat badan dan tinggi badan. Berat badan diukur dengan menggunakan timbangan badan. Anak berdiri diatas timbangan dan dilihat skala berat badan yang muncul pada timbangan badan, Satuan yang dipakai dalam pengukuran ini adalah kilogram $(\mathrm{kg})$. Tinggi badan diukur dengan menggunakan alat pengukur tinggi mikrotoa (microtoise). Tinggi badan diukur dengan cara menempelkan mikrotoa dengan paku pada dinding yang lurus datar setinggi tepat 2 meter. Angka 0 (nol) pada lantai yang datar. Lepaskan sepatu atau sandal yang dikenakan oleh anak. Anak harus berdiri tegak seperti sikap siap sempurna dalam baris- berbaris, kaki, pantat, lutut, tumit, dan kepala bagian belakang harus menempel pada dinding dan muka menghadap lurus dengan pandangan ke depan. Turunkan mikrotoa sampai rapat pada kepala bagian atas, siku-siku harus lurus menempel pada dinding. Baca angka pada skala yang nampak pada lubang dalam gulungan mikrotoa. Satuan yang dipakai dalam penelitian ini adalah centimeter $(\mathrm{cm})$.

Setelah didapatkan nilai tinggi badan dan berat badan, kemudian dihitung standar deviasi (SD) dengan menggunakan Z-score kemudian dibandingkan dengan nilai rujukan WHO-NCHS, dengan nilai ambang batas gemuk $=\mathrm{Z}$-score $>+2 \mathrm{SD}$, normal $=\mathrm{Z}$-score $+2 \mathrm{SD}$ sampai $2 \mathrm{SD}$, kurus (wasted) $=$ Z-score $-3 \mathrm{SD}$ sampai $<-2 \mathrm{SD}$, Kurus sekali $=$ Z-score $<-3$ SD. Perkembangan motorik kasar: aspek yang berhubungan dengan pergerakan dan sikap tubuh aspek yang berhubungan dengan pergerakan dan sikap tubuh yang melibatkan otot-otot besar, contohnya kemampuan untuk berdiri, duduk, menendang, berjalan, berlari, dan sebagainya yang dapat dinilai dengan tabel perkembangan anak, kemudian disimpulkan apakah anak mengalami keterlambatan perkembangan atau normal.

Besar sampel yang digunakan adalah 94 anak. Teknik pengambilan sampel yang digunakan adalah Cluster sampling. Alat dan bahan yang digunakan dalam penelitian ini adalah neraca badan (timbangan), alat pengukur tinggi mikrotoa (microtoise), tabel perkembangan anak dan alat tulis. Jenis data yang dipakai dalam penelitian ini adalah data primer yang diperoleh dari pengukuran status gizi dengan menggunakan antropometri (berat badan dan tinggi badan) dan pengukuran perkembangan motorik kasar dengan menggunakan tabel perkembangan motorik kasar anak. Analisa data menggunakan uji $\mathrm{x}^{2}(\mathrm{Cbi}$ Square) dengan kepercayaan $95 \%$ dan $\alpha=0,05$ dilanjutkan dengan uji koefisien kontingensi menggunakan program SPSS for windows versi 15.

\section{HASIL DAN PEMBAHASAN}

Status gizi adalah keadaan tubuh akibat konsumsi makanan dan penggunaan zat gizi. Status gizi dapat dibedakan antara status gizi buruk,kurang, baik, dan lebih (Almatsier, 2009) Menurut Supariasa, status gizi adalah ekspresi dari keadaan keseimbangan dalam bentuk variabel tertentu (Supariasa, 2002). Contohnya adalah Kekurangan energi protein (KEP) disebabkan oleh kekurangan makan sumber energi secara umum dan kekurangan sumber protein. (Almatsier, 2009). Indeks-indeks dalam antropometri bermanfaat untuk mengetahui proporsi, dan lebih mudah membandingkan dengan populasi lainnya. (Indriati, 2009). Berat badan memiliki hubungan yang linear dengan tinggi badan. Dalam keadaan normal, perkembangan berat badan akan searah dengan pertumbuhan tinggi badan dengan kecepatan tertentu. Jelliffe, 1966 telah memperkenalkan indeks ini untuk mengidentifikasi status gizi. Indeks $\mathrm{BB} / \mathrm{TB}$ merupakan indikator yang baik untuk menilai status gizi saat ini (sekarang). Indeks BB/TB adalah indeks yang independen terhadap umur. (Supariasa, 2002).

Pertumbuhan adalah bertambahnya ukuran dan jumlah sel serta jaringan interselular, berarti bertambahnya ukuran fisik dan struktur tubuh sebagian atau keseluruhan, sehingga dapat diukur dengan satuan panjang dan berat. Perkembangan adalah bertambahnya struktur dan fungsi tubuh yang lebih kompleks dalam kemampuan gerak kasar, gerak halus, bicara dan bahasa serta sosialisasi dan kemandirian. Pertumbuhan mempunyai dampak terhadap aspek fisik, sedangkan perkembangan berkaitan dengan pematangan fungsi organ/individu. Walaupun demikian, kedua peristiwa itu terjadi secara sinkron dalam setiap individu (Tanuwijaya, 2002). Perkembangan dan pertumbuhan diukur dengan rumus $\mathrm{Z}$ score, yaitu sebagai berikut :

\section{Nilai individu subjek - Nilai Median Baku Rujukan}

\section{Z.SCORE $=$}


Tabel 1. Klasifikasi Status Gizi

\begin{tabular}{|c|c|c|}
\hline Indeles & Status Gizi & Ambang Batas \\
\hline \multirow[t]{4}{*}{$\mathrm{BBC}$} & GiziLitabih & $2 \cdot$-scores +2 SD \\
\hline & Gizi Baik & z-scores-2SD sampsi-2SD \\
\hline & Gizi Kurang & z-score -3 sampgi<-2 SD \\
\hline & Gizi Buruk & $z$-scorec-3SD \\
\hline \multirow[t]{2}{*}{ TBU } & Normal & $2 \cdot 5 \operatorname{cose} 2-2 S D$ \\
\hline & Randel & 2 -scores +2 SD \\
\hline \multirow[t]{4}{*}{$\overline{B B T B}$} & Gamult & $2 \cdot-5 \operatorname{coses}+2$ SD \\
\hline & Normal & 2 -scores-2 $2 S D_{\text {sampsi }}+2 \mathrm{SD}$ \\
\hline & Burus (Wasted) & 2 -scorer - $2 S D_{\text {sampai }} \geq-3 S D$ \\
\hline & Kunus Sakali & 2 -scoras -3SD \\
\hline
\end{tabular}

(UKK Tumbuh Kembang - Pediatri Sosial IDAI, 2010)

Tabel 2. Tahap Perkembangan Motorik Kasar Anak menurut Umur

\begin{tabular}{|c|c|}
\hline Ysid & Tahar Reckembarcaso Motectik Kasac Anak \\
\hline 0.3 bulan & $\begin{array}{l}\text { Menganglkatkaplas setinggi } 45^{\circ} \\
\text { Menggeralkan kepala dari kici kanan ketengah }\end{array}$ \\
\hline \multirow[t]{2}{*}{$4-6$ bulan } & $\begin{array}{l}\text { Berbali dari telunglun ke telentang } \\
\text { Menganglat kepala satingsi } 90^{\circ}\end{array}$ \\
\hline & Mempectahankan posisikepala \\
\hline \multirow[t]{3}{*}{$7 \cdot 9$ bulan } & Duduk (silkan tripod-sandiri) \\
\hline & Belajar berdiri, kedua kaki menyanges sehagian beratbadan \\
\hline & Merargheak meraih mainan ataumandelati sereosang \\
\hline \multirow[t]{4}{*}{$10-12$ bulag } & Mensanglat hadan ka pesisi berdiri \\
\hline & 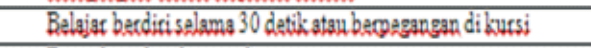 \\
\hline & Dapatbecialan dengan diturtun \\
\hline & $\begin{array}{l}\text { Mengulurkan langanbadan untuk meraih mainan yang } \\
\text { dinginkan }\end{array}$ \\
\hline \multirow[t]{3}{*}{ 13-18 bular } & Berdiri sendiri tanpa kerpesangan \\
\hline & Membungkuk memungut mainan kemudian berdicikembali \\
\hline & Sundur 5 langkah \\
\hline \multirow[t]{2}{*}{$19-24$ bulan } & Berdiri sendiri tanpa hemegangan 30 detill \\
\hline & Bergiglan tanpa terhuxung busung \\
\hline \multirow[t]{2}{*}{$25-36$ bulag } & Iglan naik tangega sendixi \\
\hline & Dapat becmain dan manandang bola keccil \\
\hline \multirow[t]{3}{*}{$37.48 \mathrm{gul} / \mathrm{aQ}$} & Bardigi 1 kaki 2 detik \\
\hline & Melowpatkeduak kaki diangkat \\
\hline & Mengaxuh sepada soda 3 \\
\hline
\end{tabular}

(UKK Tumbuh Kembang - Pediatri Sosial IDAI, 2010)

Faktor internal terdiri dari beberapa hal. Ras/etnik atau bangsa. Anak yang dilahirkan dari ras/bangsa Amerika, maka ia tidak memiliki faktor herediter ras/bangsa Indonesia atau sebaliknya. Keluarga. Ada kecenderungan keluarga yang memiliki postur tubuh tinggi, pendek, gemuk atau kurus.
Jenis kelamin. Fungsi reproduksi pada anak perempuan berkembang lebih cepat daripada laki-laki. Tetapi setelah melewati masa pubertas, pertumbuhan anak laki-laki akan lebih cepat. Genetik adalah bawaan anak yaitu potensi anak yang akan menjadi ciri khasnya. Ada beberapa kelainan genetik yang berpengaruh pada tumbuh kembang anak seperti kerdil. Kelainan kromosom umumnya disertai dengan kegagalan pertumbuhan seperti pada sindroma Down dan sindroma Turner (UKK Tumbuh Kembang - Pediatri Sosial IDAI, 2010).

Faktor eksternal terdiri dari beberapa hal termasuk faktor pranatal, persalinan, pascanatal. Faktor pranantal terdiri dari nutrisi ibu hamil terutama trimester akhir kehamilan akan mempengaruhi pertumbuhan janin. Mekanis berhubungan dengan posisi janin yang abnormal akan menyebabkan kelainan konginetal, seperti club foot. Toksin/ zat kimia. Aminoprotein dan obat kontrasepsi dapat menyebabkan kelainan kongenital seperti palatokisis.

Endokrin seperti Diabetes mellitus dapat menyebabkan makrosomia, kardiomegali dan hyperplasia adrenal. Radiasi. Radiasi pada janin sebelum umur kehamilan 18 minggu dapat menyebankan kematian janin, kerusakan otak, mikrosefali dan cacat bawaan. Misalnya pada peristiwa Hiroshima dan Nagasaki. Infeksi pada trimester pertama dan kedua oleh TORCH (toxoplasma, Rubella, Sitomegalo virus, Herpes simpleks), PMS (Penyakit Menular Seksual) serta penyakit virus lainnya dapat mengakibatkan kelainan pada janin seperti katarak, bisu, tuli, mikrosefali, retardasi mental dan kelainan jantung kongenital. Imunitas. Rhesus atau ABO inkompatibilitas sering menyebabkan abortus, hidrops fetalis, kern ikterus atau lahir mati, anoksia embrio yang disebabkan oleh gangguan fungsi plasenta menyebabkan pertumbuhan terganggu. Stres yang dialami ibu pada waktu hamil dapat mempengaruhi tumbuh kembang janin, antara lain cacat bawaan dan kelainan kejiwaan (Tanuwijaya, 2002).

Faktor persalinan berhubungan dengan komplikasi saat persalinan. Komplikasi persalinan pada bayi seperti trauma kepala dan asfiksia dapat menyebabkan kerusakan jaringan otak. Faktor pascanatal berhubungan dengan nutrisi dan perawatan setelah kelahiran/ Gizi, untuk tumbuh kembang bayi diperlukan asupan makanan yang adekuat.

Penyakit kronis atau kelainan konginetal. Tuberkulosis, anemia, kelainan jantung bawaan mengakibatkan retardasi pertumbuhan jasmani. Lingkungan fisik dan kimia. Sanitasi lingkungan yang kurang baik, kurangnya sinar matahari, paparan sinar radioaktif, zat kimia tertentu $(\mathrm{Pb}$, Mercuri, rokok, dan alkohol) mempunyai dampak yang negatif terhadap pertumbuhan anak, Psikologis, hubungan anak dengan orang sekitarnya, seorang anak yang merasa tidak dikehendaki orang tuanya atau anak yang selalu merasa tertekan akan mengalami hambatan didalam pertumbuhan dan perkembangannya Endokrin seperti gangguan hormon misalnya pada penyakit hipotiroid akan menyebabkan anak mengalami hambatan pertumbuhan. Sosio-ekonomi. Kemiskinan selalu berkaitan dengan kekurangan makanan, kesehatan lingkungan yang jelek dan ketidaktahuan, akan menghambat pertumbuhan anak. Pada lingkungan pengasuhan, interaksi ibu-anak sangat mempengaruhi tumbuh kembang anak. Stimulasi. 
Perkembangan memerlukan rangsangan khususnya dalam keluarga, misalnya penyediaan alat mainan, sosialisasi anak, keterlibatan ibu dan anggota keluarga lain terhadap kegiatan anak, Pemakaian kortikosteroid jangka panjang akan menghambat pertumbuhan, demikian juga obat perangsang terhadap susunan saraf pusat yang menyebabkan terhambatnya produksi hormon pertumbuhan. (UKK Tumbuh Kembang - Pediatri Sosial IDAI, 2010).

Memasuki masa prasekolah anak akan mulai menunjukkan keinginannya, seiring dengan pertumbuhan dan perkembangannya. Pada masa ini, selain lingkungan dalam rumah, lingkugan di luar rumah mulai diperkenalkan. Anak mulai senang bermain diluar dan berteman, bahkan banyak keluarga yang menghabiskan sebagian besar waktu bermain di luar rumah (UKK Tumbuh Kembang - Pediatri Sosial IDAI, 2010). Pada usia antara 2 dan 5 tahun, rata-rata pertambahan berat badan anak kira-kira $2 \mathrm{~kg}$ dan tinggi badan $7 \mathrm{~cm}$ setiap tahun. Bagian utama perut anak menjadi rata dan tubuh menjadi lebih langsing. Ketajaman penglihatan mencapai 20/30 pada usia 3 tahun dan $20 / 20$ pada usia 4 tahun. Semua 20 gigi primer telah muncul pada usia 3 tahun. Sebagian besar anak berjalan dengan gaya matur dan lari dengan mantap sebelum akhir tahun ketiganya. Melewati tingkat dasar ini, terdapat variasi yang luas dalam kemampuan seperti kisaran kegiatan motorik berkembang mencakup melempar, menangkap dan menendang bola, mengendarai sepeda, menaiki bangunan dilapangan, menari dan polah tingkah laku-kompleks yang lain. Tanda-tanda gaya aktivitas motorik kasar, seperti tempo, intensitas dan kewaspadaan juga sangat bervariasi karena bakat bawaan (Needlman, 1999). Nutrisi yang adekuat dan seimbang merupakan kebutuhan yang penting. Nutrisi yang dimakan, saat ditelan disebut bolus akan dicerna di sepanjang saluran pencernaan dan mengalami perubahan mekanis (mengunyah \& peristaltik) dan kimiawi (enzim-enzim pencernaan) setelah mengalami penambahan enzim lambung akan disebut kimus kemudian zat-zat energi (karbohidrat, protein dan lemak) menjadi bentuk dasarnya (glukosa, asam lemak, gliserol dan asam amino) yang akan diabsorbsi oleh vili yang berada pada usus halus (Almatsier, 2009). Hasil absorbsi akan didistribusikan ke seluruh sel tubuh untuk dimetabolisme menjadi energi atau disimpan dalam sel (glikogen dihati dan sel otot dan jaringan lemak di subkutan), saat terjadi defisiensi energi, simpanan energi ini akan dimetabolisme oleh tubuh menjadi energi untuk aktifitas tubuh (Guyton, 2007). Pada saat kimus melalui usus besar terjadi absorbsi air sehingga terbentuk sisa yang semi padat yang akan ditampung di rektum dan dikeluarkan oleh tubuh melalui anus. (Almatsier, 2009).

Glukosa, asam lemak, gliserol dan asam amino yang telah didistribusikan ke dalam sel akan bereaksi dengan oksigen, secara singkat hampir semua reaksi oksidasi terjadi didalam mitokondria dan energi yang dilepaskan, digunakan untuk membentuk senyawa berenergi tinggi (ATP). Selanjutnya, ATP yang akan digunakan diseluruh bagian sel untuk menjalankan tiga kategori utama fung4si sel, diantaranya adalah untuk menyuplai energi bagi keperluan transport natrium melalui membran sel, meningkatkan sintesa protein oleh ribosom dan untuk menyuplai energi selama kontraksi otot. Selain dimetabolisme senyawa tersebut juga disimpan, contohnya glukosa akan disimpan dalam bentuk glikogen dihati dan sel otot, dan jaringan lemak akan ditimbun disubkutan. (Guyton, 2007).

Tabel 3. Hasil dari proses pembentukan pasien

\begin{tabular}{|c|c|c|c|}
\hline$\overline{\text { No. }}$ & Tahap Metabolisme & Dikeluarkan & Dihasilkan \\
\hline \multirow[t]{2}{*}{1.} & Glikolisis & 2ATP & 4 ATP \\
\hline & & & $2 \mathrm{NADH}+\mathrm{H}$ \\
\hline 2. & Piruvat & - & $2 \mathrm{NADH}+\mathrm{H}$ \\
\hline \multirow[t]{3}{*}{3.} & Siklus TCA & - & 6NADH+H \\
\hline & & & $2 \mathrm{FADH}_{2}$ \\
\hline & & & $2 \mathrm{GTP}$ \\
\hline \multicolumn{4}{|c|}{ Total ATP yang dihas illkan: } \\
\hline \multirow[t]{2}{*}{1.} & Glikolisis & 2ATP & 4ATP \\
\hline & $2 \mathrm{NADH}+\mathrm{H}$ & & 4-6 ATP \\
\hline \multirow[t]{2}{*}{2.} & Piruvat & - & 6ATP \\
\hline & $2 \mathrm{NADH}+\mathrm{H}$ & & \\
\hline \multirow[t]{6}{*}{3.} & Siklus TCA & - & \\
\hline & $6 \mathrm{NADH}+\mathrm{H}$ & & 18 ATP \\
\hline & $2 \mathrm{FADH}_{2}$ & & 4 ATP \\
\hline & $2 \mathrm{GTP}$ & & 2 ATP \\
\hline & Jumlah & 2ATP & $38-40$ ATP \\
\hline & Hasil bersih dari $1 \mathrm{~mol}$ glukosa & & $36-38$ ATP \\
\hline
\end{tabular}

(Almatsier, 2009)

ATP selalu tersedia untuk melepaskan energinya dengan cepat dalam jumlah yang besar. Untuk mengganti ATP yang terpakai oleh sel, sejumlah reaksi kimia yang berjalan lebih lambat akan memecah karbohidrat, lemak, dan protein yang akan menggunakan energi yang dihasilkan dari reaksi tersebut untuk membentuk ATP yang baru. (Guyton, 2007). Anak yang mengalami kekurangan makanan bergizi akan menyebabkan anak lemah dan tidak aktif sehingga terjadi retardasi pertumbuhan dan perkembangan anak. Sebaliknya, anak yang mengalami kelebihan makanan bergizi akan menyebabkan obesitas yang menyebabkan anak tersebut cenderung tidak aktif, dan akhirnya akan mengganggu tumbuh kembangnya. (Suyitno, 2002).

Produk samping metabolisme sel adalah karbon dioksida yan dihasilkan dari siklus Kreb dan air yang dihasilkan oleh RTE. Melalui metabolisme energi dihasilkan dalam bentuk panas dan ATP. Glikolisis, siklus Kreb, dan RTE memungkinkan sel untuk menangkap dan menyimpan sebanyak mungkin energi kimia yang berada dalam makanan sebagai energi ATP untuk kemudian digunakan sesuai dengan kebutuhan sel tubuh (Almatsier, 2009). Enam ATP dibentuk dengan oksidasi melalui rantai transport elektron dari dua NADH yang diproduksi ketika dua mol fosfogliseraldehid dikonversi menjadi fosfogliserat. Enam ATP dibentuk dari dua NADH yang dihasilkan ketika dua mol asam piruvat menjadi asetil KoA, dan 24 ATP dibentuk pada dua putaran siklus Krebs berikutnya. Dari yang dihasilkan ini, 18 dibentuk dari oksidasi enam $\mathrm{NADH}$, 
empat dengan oksidasi dua $\mathrm{FADH}_{2}$ dan dua dengan oksidasi pada tingkat substrat ketika suksinil KoA dikonversi menjadi suksinat. Reaksi ini sebenarnya menghasilkan GTP, tetapi GTP dikonversi menjadi ATP. Jadi Produksi bersih ATP dari 1 mol glukosa adalah $2+[2 \times 3]+[2 \times 3]+[2 \times 12]=38$ (Ganong,2002).

Filamen tebal berdiameter kurang lebih dua kali dari filamen tipis. Filamen ini terdiri dari banyak molekul miosin yang mempunyai berat molekul 460.000 (Ganong, 2003). Molekul miosin terdiri atas enam rantai polipeptida, dua rantai berat, masing-masing dengan berat molekul 200.000 dan empat rantai ringan dengan berat molekul masing-masing 20.000. Dua rantai berat saling melilit satu sama lain untuk membentuk heliks ganda, yang disebut ekor dari molekul miosin. Salah satu ujung melipat secara bilateral kedalam suatu struktur polipeptida globuler yang disebut kepala miosin, sehingga terdapat dua kepala bebas pada molekul miosin heliks ganda. Empat rantai ringan juga terdapat dalam kepala miosin yang membantu mengatur fungsi kepala selama kontraksi otot. Filamen miosin dibentuk oleh 200 lebih molekul miosin tunggal. Bagian ekor molekul miosin yang terikat bersama untuk membentuk bagian dari badan filamen. Bagian kepala dari molekul menggantung keluar pada bagian samping badan. Sebagian dari badan di tiap molekul miosin juga menggantung kesamping bersama dengan kepala, sehingga menyediakan suatu lengan yang memperpanjang kepala keluar dari badan. Bagian kepala dan lengan yang menonjol bersama-sama disebut jembatan silang (cross bridge). (Guyton, 2007).

Masing-masing jembatan bersifat sangat fleksibel di dua titik yang disebut engsel, salah satu merupakan tempat lengan meninggalkan badan dan yang lain merupakan tempat kepala melekat pada lengan. Lengan berengsel akan mempermudah lengan untuk memanjang jauh keluar dari badan filamen miosin atau dibawa mendekat kearah badan. Kepala yang berengsel selanjutnya berpartisipasi pada proses kontraksi yang sebenarnya. (Ganong, 2003). Kepala miosin memiliki peran penting dalam kontraksi, yaitu berfungsi seperti enzim ATPase. Kemampuan ini menyebabkan kepala miosin memecah ATP dan menggunakan energi yang berasal dari ATP untuk menjalankan proses kontraksi. (Guyton,2007).

Filamen tipis disebut juga filamen aktin terdiri dari tiga komponen protein yaitu aktin, troponin dan tropomiosin. Kerangka filamen aktin adalah suatu molekul protein Faktin untai ganda, kedua untaian membelit suatu heliks dengan cara yang sama seperti molekul miosin. (Ganong, 2003. Setiap untai heliks F-aktin ganda terdiri atas molekul G-aktin terpolimerisasi, yang masing-masing mempunyai berat molekul sekitar 42.000. pada setiap molekul G-aktin melekat satu molekul ADP. Diperkirakan molekul ADP ini adalah bagian aktif filamen aktin yang berinteraksi dengan jembatan silang filamen miosin untuk menimbulkan kontraksi otot. Bagian aktif pada kedua untai F-aktin dari heliks ganda diatur bergantian, membentuk satu tempat aktif diseluruh filamen aktin. (Guyton, 2007).

Filamen aktin mengandung protein lain yaitu troponin dan tropomiosin. Molekul tropomiosin terbungkus secara spiral mengelilingi sisi helik F-aktin. Pada stadium istirahat, molekul tropomiosin terletak pada ujung tempat yang aktif mulai dari untai aktin, sehingga tidak dapat terjadi penarikan antara filamen aktin dan miosin untuk menimbulkan kontraksi. (Guyton,2007). Molekul troponin adalah sebuah kompleks yang terdiri dari subunit protein yang terikat secara longgar dan masing-masing memiliki peran spesifik dalam pengaturan kontraksi. Troponin I mempunyai afinitas yang kuat terhadap aktin, troponin $\mathrm{T}$ terhadap tropomiosin, dan troponin $\mathrm{C}$ terhadap ion-ion kalsium. Kompleks ini diduga untuk melekatkan tropomiosin pada aktin. Afinitas troponin yang kuat terhadap ion-ion kalsium mencetuskan proses kontraksi. (Ganong, 2003).

Penelitian ini melibatkan 122 responden sebagai sampel penelitian. Berdasarkan hasil penelitian yang tertera pada tabel 5.1 dapat diketahui bahwa sebagian besar responden berada pada rentang usia 25-36 bulan sebanyak 25 responden (20,5\%). Hal ini sesuai dengan hasil penelitian yang dilakukan oleh Bayu (2011) yang mendapatkan rentang usia 25-36 bulan menempati jumlah terbanyak ketiga yaitu 14 responden $(19,4 \%)$ dari 72 responden. Dari hasil penelitian dapat diketahui bahwa tidak terdapat selisih yang tinggi antara laki-laki dan perempuan. Selisih tersebut adalah 6 responden lebih banyak laki-laki jika dibandingkan dengan perempuan. Hal ini dikarenakan jumlah bayi dan balita yang berada dibawah wilayah kerja Puskesmas Pandanwangi jenis kelamin laki-laki sebanyak 3.159 responden (53,29\%) lebih banyak dibandingkan perempuan 2.769 responden (46,71\%) (Puskesmas Pandanwangi, 2011). Hasil penelitian ini sesuai dengan penelitian Gunawan (2010) yang menunjukkan bahwa responden pada penelitiannya lebih banyak laki-laki sejumlah 164 responden dibandingkan dengan responden perempuan 144 responden.

Hasil penelitian menunjukkan bahwa sebagian besar responden berada dalam status gizi normal dengan frekuensi sebesar 88 responden (72,1\%), 16 responden bergizi gemuk $(13,1 \%)$, responden kurus dengan frekuensi sebesar 14 responden $(11,5 \%)$, dan hanya terdapat 4 responden yang memiliki status gizi sangat kurus $(3,3 \%)$. Hal ini dikarenakan terdapat 14,09 \% anak usia bayi dan balita berada pada status gizi kurus dan 1,29 \% anak usia bayi dan balita berada pada status gizi kurus sekali (Dinkes Malang, 2010). Hasil penelitian ini sesuai dengan penelitian yang dilakukan oleh Bayu (2011) yang mendapatkan bahwa sebagian besar status gizi responden berada dalam keadaan normal sebesar $84,7 \%$, untuk status gizi gemuk sebesar 5,6\% dan untuk status gizi kurus 9,7\%. Keadaan gizi dipengaruhi oleh faktor konsumsi makanan dan faktor kesehatan. Faktor konsumsi makanan salah satunya dipengaruhi oleh pola makan anak (Supariasa, 2002).

Hasil penelitian menunjukkan bahwa terdapat 86 responden $(70,5 \%)$ yang memiliki perkembangan motorik kasar yang normal, sedangkan sisanya berada dalam keadaan keterlambatan perkembangan motorik kasar. Hal ini sesuai dengan hasil penelitian Gunawan (2010) dimana sebagian besar perkembangan motorik kasar anak normal sebesar $90,22 \%$ dan perkembangan yang mengalami keterlambatan perkembangan motorik kasar sebesar 9,75\%. Hal ini sesuai pula dengan penelitian yang dilakukan oleh Bayu (2011) yang mendapatkan $88,9 \%$ responden pada penelitiannya berada dalam status gizi normal, sedangkan yang mengalami 
keterlambatan perkembangan motorik sebesar 11,1\%. Perkembangan motorik kasar anak digambarkan dengan aktivitas yang dipengaruhi oleh pergerakan otot besar. Aktivitas tersebut diantaranya adalah kontraksi dan relaksasi. Dalam menjalankan aktifitasnya otot memerlukan energi dalam bentuk ATP yang diperoleh dari asupan nutrisi (Guyton, 2007). Keseimbangan antara asupan nutrisi dan aktivitas anak digambarkan dalam status gizi anak disimpulkan bahwa perkembangan motorik kasar anak dipengaruhi oleh status gizi anak tersebut. Perkembangan motorik kasar anak sebagian besar normal, hal ini dikarenakan sebagian besar anak memiliki status gizi normal.

Hasil penelitian menunjukkan bahwa anak yang memiliki status gizi normal lebih banyak yang memiliki perkembangan motorik kasar yang normal $78,4 \%$ dibandingkan dengan anak yang perkembangan motorik kasar yang mengalami keterlambatan perkembangan motorik kasar 21,6\%. Untuk responden yang memiliki status gizi kurus sebagian besar memiliki perkembangan motorik kasar terlambat 64,3\%, responden yang memiliki status gizi sangat kurus sekali semuanya $(100 \%)$ mengalami keterlambatan perkembangan motorik kasar. Hal ini sesuai dengan hasil penelitian Bayu (2011) yang menyatakan bahwa 84,7\% anak dengan status gizi normal berada pada perkembangan motorik kasar yang normal, dan untuk anak dengan status gizi kurus terdapat $14,29 \%$ dengan perkembangan motorik kasar normal sedangkan $85,71 \%$ mengalami keterlambatan perkembangan motorik kasar.

Analisis yang diperoleh dengan menggunakan ChiSquare didapatkan hasil koefisiensi chi-square dengan signifikansi sebesar 0,0001 . Karena signifikansi dari koefisien chi square kurang dari nilai $\alpha=0,05$,sehingga $\mathrm{H} 0$ ditolak yang artinya terdapat hubungan yang sangat signifikan antara status gizi dengan perkembangan motorik kasar. Hasil penelitian ini didukung oleh hasil penelitian Sutrisno (2003) yang dilakukan di wilayah Kecamatan Purwodadi Kabupaten Grobogan menyatakan bahwa status gizi dan tingkat kecukupan energi, protein dan zat besi berhubungan secara bermakna terhadap perkembangan motorik kasar. Didukung pula dengan hasil penelitian Bayu (2011) yang dilakukan di Puskesmas Jabung Malang, menyatakan bahwa terdapat hubungan yang signifikan antara status gizi dengan perkembangan motorik kasar pada balita. Hal tersebut dikarenakan setiap gerakan fisik memerlukan aktifitas otot yang berupa kontraksi dan relaksasi otot, untuk kontraksi dan relaksasi itu sendiri dibutuhkan energi berupa ATP yang diperoleh dari metabolisme zat-zat pembentuk energi (karbohidrat, lemak, protein). Selama aktivitas fisik terjadi, otot membutuhkan energi diluar metabolisme untuk bergerak sedangkan jantung dan paru-paru membutuhkan tambahan energi untuk mengantarkan zat-zat gizi dan oksigen ke seluruh tubuh dan untuk mengeluarkan hasil sisa metabolisme tubuh. (Almatsier, 2009).

Perkembangan anak sangat dipengaruhi oleh otak. Otak mengatur setiap gerakan yang dilakukan oleh anak. Semakin matangnya sistem saraf otak memungkinkan berkembangnya perkembangan anak (UKK Tumbuh Kembang - Pediatri Sosial IDAI, 2010). Seperti halnya organ tubuh yang lain otak juga membutuhkan energi untuk perkembangan otak itu sendiri. Otak mencapai bentuk maksimal pada usia dua tahun. Kekurangan gizi dapat berakibat terganggunya fungsi otak secara permanen (Almatsier,2001). Sehingga dapat disimpulkan kebutuhan energi untuk perkembangan anak tidak hanya untuk aktifitas tetapi juga untuk perkembangan otak, sehingga jika terjadi kekurangan asupan nutrisi akan mengakibatkan keterlambatan perkembangan (Almatsier, 2009).

Hasil penelitian didapatkan responden yang memiliki status gizi gemuk, sebagian besar diantaranya 9,8\% memiliki perkembangan motorik kasar yang normal, tetapi terdapat juga responden yang memiliki status gizi gemuk yang mengalami keterlambatan perkembangan motorik kasar. Hasil penelitian ini didukung dengan penelitian dari Bayu (2011) yang mendapatkan responden dengan status gizi gemuk sebesar 50\% mengalami keterlambatan perkembangan motorik kasar dan 50\% mengalami perkembangan motorik kasar yang normal. Hal ini sesuai dengan pendapat Soetjiningsih (2002) Kelebihan energi akan diubah menjadi simpanan lemak dalam tubuh, akibatnya terjadi berat badan lebih atau kegemukan. Obesitas dapat menimbulkan gangguan perkembangan motorik, tetapi tidak semua anak obesitas mengalami gangguan perkembangan motorik. (Soetjiningsih, 2002).

Hasil penelitian didapatkan pula responden yang mengalami keterlambatan perkembangan motorik kasar pada responden dengan status gizi normal dan pada anak dengan status gizi kurus memiliki perkembangan motorik kasar yang normal. Hal ini sesuai dengan penelitian Gunawan (2010) yang menunjukkan bahwa terjadi keterlambatan perkembangan anak pada status gizi normal $(0,23 \%)$ dan pada anak dengan status gizi kurus mengalami perkembangan yang normal (77,6\%). Hal ini dikarenakan perkembangan anak tidak hanya diperngaruhi oleh asupan nutrisi yang digambarkan dalam status gizinya. Perkembangan dipengaruhi oleh terpenuhinya kebutuhan dasar anak, diantaranya adalah kebutuhan fisik-biomedis, kebutuhan emosi atau kasih sayang dan kebutuhan akan stimulasi yang dikenal dengan asuh, asih, dan asah (UKK Tumbuh Kembang - Pediatri Sosial IDAI, 2010).

Pemenuhan nutrisi termasuk dalam pemenuhan fisikbiomedis. Faktor lain yang ikut mempengaruhi perkembangan motorik kasar anak adalah ada tidaknya stimulasi dari orang tua. Stimulasi merupakan awal proses belajar anak dan akan mempengaruhi proses perkembangan anak selanjutnya (Suganda, 2002). Pada awal kehidupan terjadi optimalisasi dari perkembangan otak, sehingga jika anak mendapat stimulasi yang baik maka akan mengalami perkembangan motorik kasar yang normal. Dan jika anak kurang mendapat stimulasi maka anak cenderung mengalami keterlambatan perkembangan motorik kasar. Ada tidaknya saudara juga mempengaruhi perkembangan motorik kasar anak. Anak selain anak pertama ataupun anak tunggal dengan status gizi kurang mempunyai teman untuk bermain dan beraktivitas selain dengan orang tuanya sehingga anak tersebut memiliki perkembangan motorik kasar yang bagus karena mendapat stimulasi untuk melakukan aktivitas dan bermain yang biasanya dilakukan oleh saudara kandungnya (Soetjiningsih, 2002). 
Tabel 4. Distribusi frekuensi responden berdasarkan usia

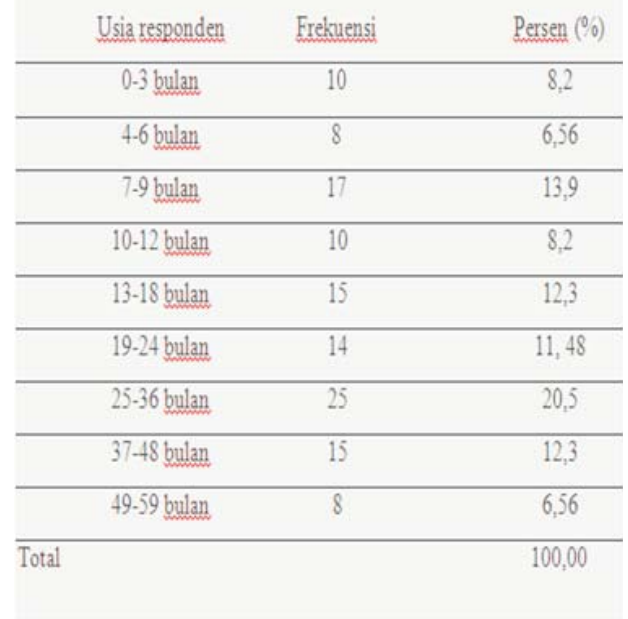

(Data primer yang diolah, 2012)

Tabel 4. Distribusi responden berdasarkan status gizi

\begin{tabular}{ccc} 
Status Gizi & Frekuensi & Persen $(\%)$ \\
\hline Kunus sekali & 4 & 3,3 \\
\hline Kunus & 14 & 11,5 \\
\hline Nomal & 88 & 72,1 \\
\hline Gemuk & 16 & 13,1 \\
\hline Total & 122 & 100,0
\end{tabular}

(Data primer yang diolah, 2012)

Tabel 5. Distribusi frekuensi responden berdasarkan perkembangan motorik kasar

\begin{tabular}{ccc} 
Perkembangan motoril' kasar & Frekuensi & Persen $(\%)$ \\
\hline Nomal & 86 & 70,5 \\
\hline Terlambat & 36 & 29,5 \\
\hline Total & 122 & 100,0
\end{tabular}

(Data primer yang diolah, 2012)

Tabel 6. Distribusi frekuensi responden berdasarkan status gizi dan perkembangan motorik kasar

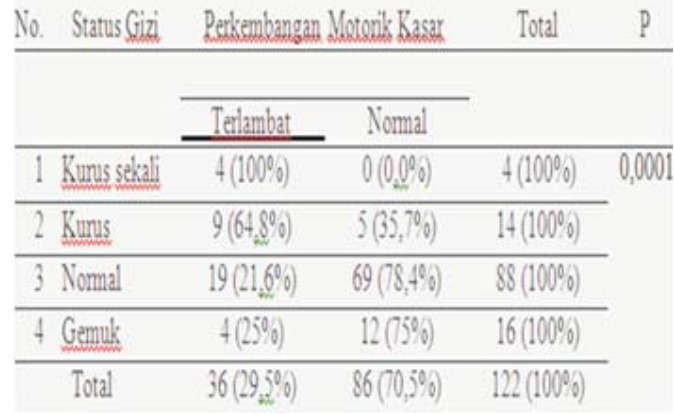

(Data primer yang diolah, 2012)

\section{SIMPULAN}

Kesimpulan hasil penelitian hubungan antara status gizi dengan perkembangan motorik kasar anak usia bayi dan balita (0-59 bulan) di puskesmas Pandanwangi Kota Malang adalah terdapat hubungan antara status gizi dengan perkembangan motorik kasar anak usia bayi dan balita (0-59 bulan) di wilayah kerja puskesmas Pandanwangi kota Malang. Anak usia bayi dan balita yang berada di wilayah kerja puskesmas Pandanwangi kota Malang sebagian besar berada pada status gizi normal yaitu sebanyak 88 anak $(72,1 \%)$, dan diikuti dengan status gizi gemuk sebanyak 16 anak $(13,1 \%)$, kurus 14 anak (11,5\%) dan kurus sekali 4 anak (3,3\%). Anak usia bayi dan balita yang berada di wilayah kerja puskesmas Pandanwangi kota Malang sebagian besar memiliki perkembangan motorik kasar normal sebanyak 86 anak $(70,5 \%)$, tetapi masih terdapat yang mengalami keterlambatan perkembangan motorik kasar sebanyak 36 anak (29,5\%).

\section{DAFTAR PUSTAKA.}

Almatsier, Sunita. 2009. Prinsip Dasar Imu Giži. Gramedia Pustaka Utama. Jakarta : Bagian Ilmu Kesehatan Anak Fakultas Kedokteran Universitas Indonesia. 1985.

Pertumbuban dan Perkembangan . In: Rusepno Hasan., Husein Alatas. Imu Kesehatan Anak. Fakultas Kedokteran Universitas Indonesia. Jakarta. pp 145-168.

Baker, Helen. Sally Grantham. 2009. Giži Dan Perkembangan Anak In: Helen Baker, Sally Grantham, Henningham, Mc Gregor. Gizi Kesehatan Masyarakat. ECG. Jakarta. pp 579-593.

Bayu, Yotin. 2011. Hubungan Antara Status Gizi Dengan Perkembangan Motorik Kasar Pada Anak Usia Bayi Dan Balita 13-59 Bulan di Wilayah Kerja Puskesmas Jabung. Universitas Muhammadiyah Malang. Malang. Pp 28-31.

Depkes Jatim. 2006, Deteksi Dini Tanda dan Gejala Penyimpangan Dan Pertumbuban Anak Untuk Dokter dan Pelayanan Kesehatan Lini Pertama. Surabaya.

Depkes RI. 2002. SK Mentri Kesehatan RI No: 920/Menkes/ SK/VIII/2002 Tentang Klasifikasi Status Giri Anak Bawah Lima Tabun (Balita). downloaded 10 Oktober2010. <http://www.depkesri.gov/ KMK920-0802-G.pdf>.

Depsos RI. 2006. Balita Gizi Buruk. downloaded 10 Oktober 2011. <http://www.depsos.go.id/modules.php? name $=$ News $\&$ file $=$ print $\&$ sid $=280>$.

Dinkes Malang. 2010. Hasil Operasional Posyandu di Kota Malang Tahun 2010. Malang

Ganong, William F. Buku Ajar Fisiologi Kedokteran (Review of Medical Physiology). Edisi 20. Jakarta. EGC. 2002.

Gunawan, Gladys; Fadlyana Eddy; Rusmil, Kusnandi. 2011. Hubungan Status Gizi dan Perkembangan Anak Usia 1-2 Tahun. Sari Pediatri. Volume 13. Pp 142-146.

Guyton, Arthur C. John E. Hall. Buku Ajar Fisiologi Kedokteran (Textbook of Medical Physiology). Edisi 11. Jakarta. EGC. 2007.

IDAI. 2010, Deteksi Dini Tanda dan Gejala Penyimpangan Dan Pertumbuban Anak. Sagung Seto. Jakarta: UKK Tumbuh Kembang - Pediatri Sosial IDAI

Indriati, Etty. 2009. Antropometri Untuk Kedokteran, Keperawatan, Gizi dan Olahraga. Citra Aji Parama. Yogyakarta. 
Muray, Robert K. et. al. Biokimia Harper (Harper's Biochemistry). Edisi 25. Jakarta. EGC. 2003.

Needlman, Robert D. 1999. Pertumbuban dan Perkembangan. In: Richard E. Behrman, Robert M. Kleigman, Ann M. Arvin. Ilmu Kesehatan Anak Nelson (Nelson Textbook of Pediatric) Vol 1. Edisi 15. EGC. Jakarta. Pp 37-90.

Nugroho, Heru Santoso Wahito. 2009. Petunjuk Praktis Denver Developmental Screening Test. Jakarta: EGC

Puskesmas Pandanwangi Malang. 2010. Jumlah Penduduk Desember 2011 \& Sasaran Program Kesehatan Tabun 2011 Dan 2012. Malang

Supariasa, IDN, dkk. 2002. Antropometri Gizi. In: Penilaian Status Gizi. EGC. Jakarta. pp. 27-87.

Supariasa, IDN, dkk. 2002. Konsep Dasar Timbulnya Masalah Gizi. In: Penilaian Status Gizi. EGC. Jakarta. pp. 1-16.

Supariasa, IDN, dkk. 2002. Metode Penilaian Status Giz̨i. In: Penilaian Status Gizi. EGC. Jakarta. pp. 17-26.

Sutrisno. 2003. Hubungan Status Giri Dengan Tingkat Perkembangan Motorik Kasar Anak Usia 2 - 3 tahun pada Keluarga Sejabtera Di Wilayah Kecamatan Purwodadi Kabupaten Grobogan - Jawa Tengah. Undergraduate Thesis. Universitas Diponegoro. Semarang

Suyitno, Hariono. 2002. Pertumbuban Fisik Anak. In: Moersintowati B Narendra, Tumbub Kembang Anak dan Remaja. Edisi 1. Sagung Seto. Jakarta. pp 51-61.

Suyitno, Hariono. 2002. Pertumbuban Fisik Anak. In: Moersintowati B Narendra.Tumbub Kembang Anak dan Remaja. Edisi 1. Sagung Seto. Jakarta. pp 51-61.

Tanuwijaya, Suganda. 2002. Kebutuhan Dasar Tumbuh Kembang Anak. In: Moersintowati B Narendra. Tumbub Kembang Anak dan Remaja. Edisi 1. Sagung Seto. Jakarta: IDAI. pp 13-19, 2001. 